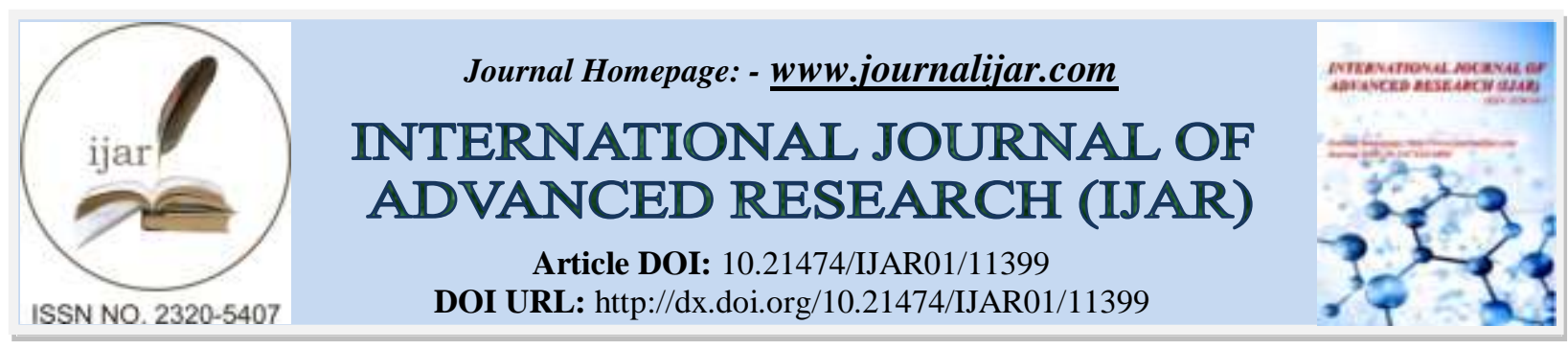

RESEARCH ARTICLE

\title{
SUSTAINABILITY VARIABLES AND INDICATORS SMALL ISLANDS: LITERATURE REVIEW
}

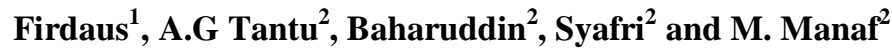

1. Students of Doctoral Studies in Urban and Regional Planning at Bosowa University, Makassar, 90231, Indonesia.

2. Lecturer in the Doctoral Study Program at Urban and Regional Planning at Bosowa University, Makassar, 90231, Indonesia.

\section{Manuscript Info}

Manuscript History

Received: 25 May 2020

Final Accepted: 28 June 2020

Published: July 2020

Key words:-

Variables, Indicators, Sustainability, Small Islands

\section{Abstract}

The development of small islands in the last few decades has not shown optimal and sustainable results. This problem occurs on small islands with a high population density coupled with high socio-cultural and economic activities with dense settlements as estimating indicators. This study aims to determine the variables and indicators that are able to formulate an index of the sustainability of small island development. This research method uses a scientific literature study approach related to the sustainability of development and management of small islands so that from the literature review, the most appropriate variables and indicators are used to formulate a new index in determining the sustainability of small island development.

Copy Right, IJAR, 2020,. All rights reserved.

\section{Introduction:-}

The development of small islands so far has not shown optimal results and their development does not lead to sustainable development (Supriatna, 2007). This happens on islands that have a population density that is equipped with dense settlements. The high population with limited land has an impact on the symptoms of environmental damage including pollution and resulting in the degradation of marine ecosystems such as mangroves and sea fish. According to Budiharjo and Sujarto (1999), the development of the islands also needs to be expressed various developments in ideas, thoughts and approaches that are sustainable.

Sustainable development is a way of looking at activities carried out systematically and planned in the framework of improving the welfare, quality of life and the environment of mankind without reducing access and opportunities for future generations to enjoy and use them. In the process of sustainable development there is a planned change process, in which there is exploitation of resources, direction of investment in technological development orientation, and institutional changes, all of which are in harmony, and increase the potential of the present and the future to meet the needs and aspirations of the community (Burhanuddin et al ., 2012). According to Sarte (2010),

From many studies in the field of sustainable development, the size of the criteria and the number of research indicators must be limited, because the number of criteria that are too large will confuse decision makers. But too few criteria, on the other hand, might not be enough to provide all the relevant information needed(Pourebrahim, Hadipour et al. 2010). To evaluate the sustainability of an area's development objectively, we must build an index system especially for island areas which are still rather rare (Zhou, Xiao et al, 2007). 
As discussed by Susilo, (2007) sustainable development in small islands must cover at least 3 aspects, namely ecological, economic, and social. The ecological, economic and social benefits that are obtained as a result of the development must be substantial in fact must also be balanced in all aspects. The imbalance between these aspects as a result of environmental pollution, over-exploitation of natural resources, the benefits of uneven use of natural resources in the community, the emergence of individualistic characteristics and violations of laws and regulations, for example, will result in the development of small islands becoming unsustainable. In the research conducted by (Susiolo, 2007) indeed only two variables were studied which represented two important aspects of sustainable development, namely ecological and economic aspects.

The sustainability index of small island development that will be prepared is a tool to assess the sustainability of small islands in terms of sustainable regional development. The preparation of this index can help establish a sustainable development of the environment and help to shape the direction of the development of small islands in order to create a good environment. So we need an approach that is able to solve the problem of developing small islands while still paying attention to the main sustainability principles related to the socio-cultural, economic and ecological aspects.

This study aims to determine the most appropriate variables and indicators in formulating the small island development index. It is hoped that this research can be used in modeling the planning and management of small islands in Indonesia in a sustainable manner.

\section{Research Methods:-}

This research is a literature study by examining 27 journals related to the sustainability of development and management of small islands. The study of scientific literature on previous research is described based on the method and the results of the research and then made in the form of a matrix of indicators used, so that the results will be obtained with the most appropriate variables and indicators to be formulated as an index of the sustainability of small island development.

\section{Results and Discussion:- \\ Sustainability Index:}

Sustainable development is a process of change from various development attributes that interact with each other to achieve development goals, namely a balance between socio-economic benefits and the preservation of natural resources. An assessment of the sustainability of development can be carried out at the "process" stage as well as at the outcome stage.

The assessment of the sustainability of small island development can be done through two approaches, namely the assessment of all development attributes and an assessment of the balance between socio-economic benefits and the preservation of natural resources and the environment or what is known as an economic-ecological (or ecologicaleconomic) model. One of the natural resources in the environment of small islands is the marine fish resource which is used by local fishermen as a source of economic activity for the local community.

The assessment approach to the goals of sustainable small island development is to assess how far there has been a balance between socio-economic benefits and the preservation of natural resources and the environment. This approach is known as the economic-ecological model or the bioeconomic model (Susilo, 2007).

The sustainability index of the waterfront area is the process of evaluating and grouping certain indices in terms of the sustainability of its users. Sustainability indexes can help stakeholders to develop coastal plans that are environmentally friendly both directly and indirectly in reducing the negative impacts of developing marine ecosystems (Feng et al., 2014). Furthermore, based on the ecological theory of the city, the variables related to determining the sustainability of the city will be analyzed using the equation model / structural data analysis technique (SEM) which is one of the multivariate analyzes analyzing the relationship of complex and simultaneous variables (Azwar et al., 2013).

Solving urban problems including in coastal areas can be done with the concept of sustainable cities which have also become an option in the late twentieth century. Sustainable cities basically means a cohesive relationship between the city and the environment. Sustainable cities must realize that cities need to meet social, 
environmental, political and cultural and economic and physical goals (Baldemir, E., et al, 2013). As happened in various coastal cities, for example Semarang, which is a coastal area development activity and as well as responding to problems and challenges of development, is carried out designing a management policy design based on the concept of sustainable edge city in the form of policy and strategy directives (Laras et al., 2011).

\section{Previous studies related to sustainable development and management of small islands:}

In this section, we will explain the position of research on previous theories or studies that discuss sustainability indices and models as well as the development of small islands. From the results of the study of previous studies, we will see the difference from previous studies that examine the index and sustainability model, especially in the sorting of variables and indicators used so that this research will be found novelty which will strengthen and develop the concept of the formulation of a sustainable development index that has been widely developed.

Research conducted by Liangju Yu in 2010, titled research Assessment of sustainable development of coastal zones: A case study from Yantai, China has the aim of introducing an assessment of coastal development progress, designed with indicators representing environmental subsystems (ENS), social subsystems (SOS) and economic subsystems (ECS), index variables used are population density, number of researchers, proportion of research and DGP, level of contribution of science and technology.

In a study conducted by Amiruddin Tahir in 2012, with the title Small Island Vulnerability Index: The Case of Barrang Lompo-Makasar Island aims to determine parameters that affect small island vulnerability, calculate and project vulnerability index of small islands, and design strategies adaptation to changes in sea level, the variables used are sea level rise SR), beach erosion (ER), wave height (GL), average tide (PS), tsunami events (TS), growth (PD) and density resident (KP), elevation (EL) and slope (SL), coastal typology (TP), land use (PL), residential settlement (PP) typology, coastal habitat (HP), mangrove ecosystem (MR), coral reef ecosystem ( TK), seagrass beds (LM) and marine conservation (KL).

Research conducted by Sylvira A. Azwar in 2013, titled the model of sustainable urban infrastructure in the reclamation of the north coast of Jakarta, aims to examine the concept of sustainable urban infrastructure in the reclamation of the north coast of Jakarta, which is an approach that integrates the urban development component of the capital community, namely urban infrastructure needs and city ecological components, with index variables: land use, transportation, open space buildings, infrastructure and energy networks.

Furthermore, the research conducted by Citra Persada in 2014, entitled Determination of the Status of Urban Infrastructure Sustainability (Case Study: Bandarlampung City), aims to formulate criteria and indicators of urban sustainable infrastructure development, assess the level or status of sustainability of urban infrastructure and identify influential factors in development urban sustainable infrastructure, the variables used are environmental criteria, social criteria, economic criteria and technological criteria and governance criteria.

Research by Chengdong Wang in 2016, titled Measuring regional sustainability with an integrated socio-economicnatural approach: a case study from the Yellow River Delta region in China aims to provide a reference standard for measuring regional sustainability, the index variable used is the Social subsystem energy, energy per capita and population empowerment, energy economy subsystem, use of individual fuel, electricity to total energy ratio, energy / dollar ratio, investment ratio of energy subsystem natural energy.

Research conducted by Andi Yurnita in 2017, with the title Sustainable Model of Beach Reclamation Case: Makassar City Beach, aims to formulate a reclamation model that can be applied to coastal areas using a sustainability index, in this study the researchers determined the sustainability index in aspects based on aspects physical (buildings, infrastructure and coastal resources) applied to the reclamation site.

In a study conducted by Suparman Supardi in 2017, with the title Analysis of Sustainable Development of Coastal Cities (Case Study: Baubau City, Southeast Sulawesi Province), aims to analyze the sustainability of Baubau City development based on ecological, economic, social, infrastructure and technology dimensions, and law and institutional. The results showed that Baubau City was quite sustainable in the technological infrastructure dimension (74.77) and the institutional legal dimension (65.87), but not sustainable in the ecological dimension (32.90) and the economic dimension (41.87), and was not sustainable in the social dimension $(20,61)$. 
The research conducted by Edwarsyah, Rina Safrina in 2017, with the title The Status and Sustainability Status of Outermost Small Islands: Case Study of the Pulo Raya Coastal Area of Aceh Jaya, aims to identify the potential of the coastal natural resources of Pulo Raya Island and assess the status of the coastal sustainability index of Pulo Raya Island. Sustainability analysis is carried out using the Rapfish approach. Rapfish analysis is carried out on five dimensions (ecology, economics, socio-culture, technology, and institutions). Attributes on each dimension / factor most influential are the condition of the aquatic environment (ecological dimension); profitability of seaweed cultivation (economic dimension); social togetherness (social cultural dimension); type of vehicle (technological dimension); and the availability of fisheries groups.

After reviewing the previous studies and theories that have been carried out, it can be said that there have been many studies that formulate sustainability variables and indicators, especially in urban and coastal areas, but have not shown specifically the arrangement of variables and indicators in the development of small islands, so that indeed a research is needed to analyze the sustainability index that is most suitable for use in small islands. The index that has not yet been formulated is the sustainability index for the development of small islands and is then used as the basis for developing models of sustainable island development as a basis for regional development policies.

The following is a diagram of the research position of the studies that have been carried out related to sustainable development and small islands:

Research on Small Islands

1. Small Istand Vulnerability Index: The Case of Barang LampoMakassar Island (Thhir. 2009).

2. Sustainability analysis Development of small islands: An ecologicaleconomic model approach (Susilo, 2007).

3. Priority for Sustainable Infrastructure Development on Betrang Lorme Island by Using AHP (Analytical Hierarchy Process) Method (Bushanuddio, 2012)

4. Vulnerability assessment of ecological conditions in the Thousand Islands, Indonesia (Eahan, 2012)

5. Study on Clean Water Supply Systems in Barang Lampo. Island Ujung Tanah District (Selinotrg, 2012).

6. Evaluation of Small Island as a Basis for Ecotourism Investment Development (Case Study of Tidung Kecil Island, Kepulauan Seribu Regency, Dki) (Widodo, 2015)

7. Constraints and Strategies for Waste Management in Barang Lamph. Island (Mandala, 2016)

8. Index and Status of Sustainability of Ovtermost Small Islands: Case/ Study of the Pulo Raya Coastal Acen Jaya (Edwarsyah, 2017)

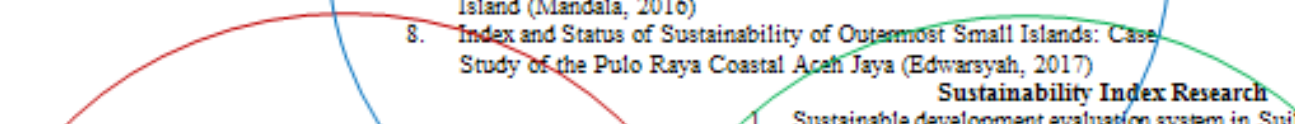

\section{Research on Sustainability Index Models}

1. Fowards modeling of sustainability into urban planning: Using Indicators to build sustainable cities (Rosales M. 2011)

2. Sustainable Urban Infrastructure Model on the North Jakarta

Coastal Reclamation (Azwor, 2013).

3. Quantitative models for assessing human-ocean systems of sustainable development in coastal cities: a metabolic perspective of recycling in the Bohai sea ring area, China (Qin, 2015).

4 Use modeling tools to implement appropriate land use and natural conservation management systems on small islands Case study of Pico Island (Azores) (Femandes, 2017).

5. Pynamic Model of Vulnerability in Roteran Island and Giti Dawak Beach, Sumenep Madura Regency (Wurdhani, 2017)

6. Sustainable Coastal Reclamation Model Case: Makassar City Beach (Andi Y, 2017)

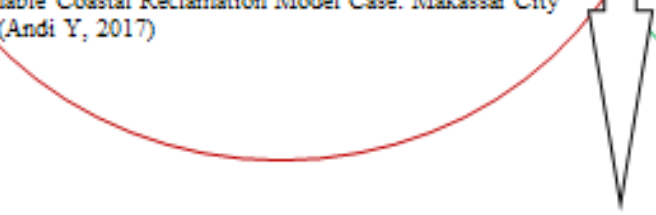

Sustainable development evaluation system in Suitug City, China

(Iia, 2007)

2. Indicators of Sustainability of Cities in Indonesia: Comparative Study of Four Cities in Java (Setiassan, 2007)

3. Measurement indicators and evaluation approaches for asjessing urban sustainable development: A case study for Jining City in China (Eens, 2009).

7. Assessment of sustainable development of coastal zones: A case study from Xantai, China (Yu, 2010)

5. Analytic network process selection criteria in planning sustainable coastal land use (Rourebrahim, 2010)

6. Determination of Urban Infrastructure Sustainability Status (Case Study: Kota Randerlamgung) (Rersada C, 2014).

7. Measuring sustainability of the region in an integrated mander socio-aconomic-nature approach: a case study from the Yellow River Delta region in China (Wang, 2016)

8. Develop key sustainability indicators to assess the performance of green infrastructure (Pakzad, 2017).

9. Analysis of Sustainable Coastal Urban Development (Case Study: Bavbau City, Southeast Sulawesi Province) (Sopardi, 2017)

10. Sustainability Index of Marine and Cosetal Resources at Bali's Benoa Bay Reclamation Location-(Handadari, 2018)

Within the scope of the methodology, research needs to develop new variables and indicators from the sociocultural, econom ic and ecological a spects that will form ulate new index es and models in the developm ent of sm all islands.

In the scope of substance, in general this research develops the sustainability model of small island developm ent and specifically develops priority indicators for the sustainability of sm all island developm ent.

Figure 1:- Position in previous studies. 
The study of journals related to sustainable development which will be the basis of researchers in developing variables and indicators that are most appropriate in formulating the sustainability of small island development.

Table 1:- Position of research on the arrangement of variables and indicators of development sustainability.

\begin{tabular}{|c|c|c|c|c|c|c|c|c|c|c|c|c|c|c|c|c|c|c|c|c|c|c|c|c|c|c|c|c|c|c|c|c|c|c|c|c|}
\hline \multirow[b]{2}{*}{ No. } & \multirow[b]{2}{*}{$\begin{array}{l}\text { Restarcber' } \\
\text { Year }\end{array}$} & \multicolumn{10}{|c|}{ Secio Cultural Variable } & \multicolumn{12}{|c|}{ Econamic Variables } & \multicolumn{13}{|c|}{ Ecological Variables } \\
\hline & & 音 & 8 & $\begin{array}{l}\frac{y}{y} \\
y \\
= \\
=\end{array}$ & $\frac{8}{8}$ & $\begin{array}{l}\frac{1}{3} \\
\frac{3}{3} \\
\frac{3}{3}\end{array}$ & 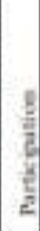 & $\frac{8}{8}$ & $\begin{array}{l}3 \\
3 \\
3 \\
3\end{array}$ & $\begin{array}{l}\text { v } \\
3 \\
3\end{array}$ & $\begin{array}{l}8 \\
-1 \\
\frac{1}{2} \\
-1\end{array}$ & 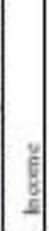 & $\begin{array}{l} \\
5 \\
3 \\
5 \\
2\end{array}$ & 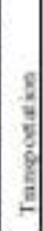 & 吾 & $\begin{array}{l}0 \\
\text { y } \\
\text { y } \\
\text { y. }\end{array}$ & $\begin{array}{l}3 \\
3 \\
3\end{array}$ & 플 & $\begin{array}{l}8 \\
8 \\
8\end{array}$ & 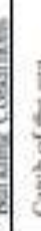 & 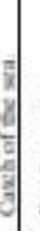 & 章 & $=$ & . & $\begin{array}{l}0 \\
\frac{8}{8} \\
\frac{8}{8}\end{array}$ & $\frac{5}{2}$ & 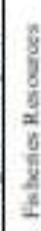 & & 3 & $\begin{array}{l}y \\
8 \\
8 \\
8 \\
y \\
y\end{array}$ & 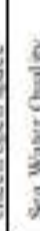 & 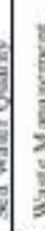 & 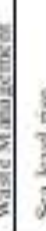 & & & \\
\hline 1 & $\begin{array}{l}\text { ZHOU Jia, } \\
2000\end{array}$ & & $\sqrt{1}$ & & & & & & & & & $\sqrt{1}$ & & & & & & & $\sqrt{ }$ & & ( & $\checkmark$ & $\sqrt{ }$ & & & & & & & & & $\sqrt{ }$ & & & & \\
\hline 2 & $\begin{array}{l}\text { Setiawain, } \\
2007 \\
\end{array}$ & & & & & & & & & & & & & & & $\sqrt{\gamma}$ & $\mathrm{v}$ & & & & & & & & & & & & & $\sqrt{ }$ & & $\nabla$ & & $\checkmark$ & & \\
\hline 3 & Susilo, 2007 & & & & & & & & & & & & $\sqrt{1}$ & & & & & & & A & 1 & v & & 1 & $\sqrt{1}$ & 8 & $\mathrm{v}$ & & $\mathrm{v}$ & & $\sqrt{v}$ & & & & & \\
\hline 4 & Feng L.i, 2009 & & & & & & 8 & & & $\sqrt{1}$ & & 1 & & & & & & & & & & & $\nabla$ & & -1 & - & & & 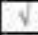 & & & & & 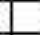 & & \\
\hline 5 & \begin{tabular}{|l} 
Limpju \\
2010
\end{tabular} & $\sqrt{ }$ & & & & & & & & & & & & & & & & & & & & & $\sqrt{ }$ & & & & & & $\sqrt{ }$ & & & & & $\checkmark$ & & \\
\hline 6 & $\begin{array}{l}\text { Pourebrahim, } \\
2010\end{array}$ & & $\sqrt{8}$ & & & & & & & & & & & $\sqrt{1}$ & & & & & & & & & & & & & & & & & & & & & & \\
\hline 7 & \begin{tabular}{|l|} 
Rosales, 201I \\
\end{tabular} & & & & & & & & & & & & & & $v^{2}$ & $\mathrm{~V}$ & 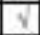 & & & & & & & & & & & & & & & & & & & \\
\hline 8 & Farhan, 2012 & & $\mathrm{D}$ & & & & & & & & & & & & & & & & & & & & & 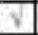 & V & 8 & & 7 & . & & - & & - & & 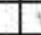 & V \\
\hline 9 & Tahir, 2012 & & $\sqrt{7}$ & & & & & & & & & & & & & & & & & & & & & 1 & $\sqrt{1}$ & $\sqrt{1}$ & $\mathrm{~V}$ & $\sqrt{7}$ & $\sqrt{v}$ & & $\sqrt{v}$ & & $\nabla$ & & F & $\nabla$ \\
\hline 10 & $\begin{array}{l}\text { Burhinudidin, } \\
2012 \\
\end{array}$ & & & & & & & & & & & & & 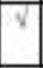 & & $\sqrt{1}$ & $x$ & & & & & & & & & & & & & & & $\sqrt{1}$ & & & & \\
\hline 11 & Axwar, 2013 & & & & & & & & & & & & & v & $\sqrt{2}$ & & & & $\sqrt{ }$ & & & & & & & & & & & $v$ & & & & & - & $\checkmark$ \\
\hline 12 & $\begin{array}{l}\text { Selintuing, } \\
2013\end{array}$ & & & & & & & & & & & & & & & & $\sqrt{1}$ & & & & & & & & & & & & & & & & & & & \\
\hline 13 & \begin{tabular}{|l} 
Persada, 2014 \\
\end{tabular} & $\sqrt{2}$ & $\sqrt{1}$ & 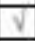 & $\sqrt{3}$ & & $\sqrt{ }$ & & $\mathrm{V}$ & & $\sqrt{1}$ & 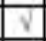 & $\sqrt{1}$ & $\sqrt{8}$ & & $\mathrm{y}$ & $\sqrt{ }$ & & v & & 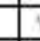 & V & $\sqrt{1}$ & & & & & & & $\sqrt{v}$ & & $\checkmark$ & & 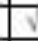 & $\sqrt{5}$ & V \\
\hline 14 & $\begin{array}{ll}\text { Xiong gin. } \\
2015\end{array}$ & & & & & & & & & & & & & & & & & & & & & & $\sqrt{V}$ & & & & $\sqrt{5}$ & & $\sqrt{ }$ & & & & & & & \\
\hline 15 & Widodo, 2015 & $\sqrt{1}$ & $\sqrt{7}$ & & & $\sqrt{1}$ & $\sqrt{ }$ & & & $\sqrt{1}$ & $\sqrt{ }$ & & & $\sqrt{ }$ & & & $\sqrt{1}$ & & & & & & $\sqrt{1}$ & $\sqrt{1}$ & $\sqrt{1}$ & $\sqrt{2}$ & $\sqrt{2}$ & $\sqrt{7}$ & $\sqrt{v}$ & $\sqrt{ }$ & & & $\checkmark$ & & & \\
\hline 16 & Karlina, 2015 & & & & & & $\sqrt{ }$ & $\sqrt{ }$ & $\sqrt{ }$ & v & $\sqrt{1}$ & $\sqrt{1}$ & & & & & & & & & 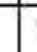 & $\bar{v}$ & & & & & & & & & & & & & & \\
\hline 17 & Wang. 2016 & & IV & & & \begin{tabular}{|l|l} 
& \\
\end{tabular} & 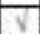 & & & & & & 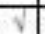 & & 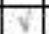 & & & & & & & & & & & & & & & & & & & & 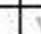 & v \\
\hline 18 & $\begin{array}{l}\text { Mandaln, } \\
2016\end{array}$ & & $\sqrt{1}$ & & $\sqrt{1}$ & $\sqrt{1}$ & $\sqrt{ }$ & $\sqrt{v}$ & & & & & & & & $\sqrt{1}$ & & & & & & & & & & & & & 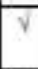 & & $\sqrt{v}$ & $\sqrt{ }$ & & & & \\
\hline 19 & $\begin{array}{l}\text { Femandes, } \\
2017\end{array}$ & & $\sqrt{1}$ & & & & & & & $\sqrt{1}$ & & $\sqrt{18}$ & & & & & & & & & & & & & & & & & $\sqrt{ }$ & $\sqrt{ }$ & $\checkmark$ & & & & 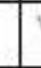 & $\sqrt{7}$ \\
\hline 20 & \begin{tabular}{|l|l} 
Palczad, 2017 \\
\end{tabular} & & & & & & & & & v & & & & v & & & $\sqrt{1}$ & 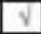 & & & & & & $\bar{N}$ & $\checkmark$ & $\sqrt{8}$ & & $\sqrt{1}$ & $\mathrm{v}$ & & & & 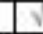 & & & \\
\hline 21 & \begin{tabular}{|l|} 
Wardlhani, \\
2017 \\
\end{tabular} & & 8 & & & & & & & & & & & & & & & & $\sqrt{\sqrt{v}}$ & & & & & $\nabla$ & 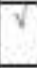 & 8 & $\sqrt{2}$ & $\sqrt{7}$ & & & $\nabla$ & & 7 & & & \\
\hline 22 & Andi Y, 2017 & & & & & & & & & & & & & v & & & & & $\sqrt{ }$ & & & & & - & & & $\sqrt{ }$ & & v & $\sqrt{ }$ & & & & & 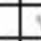 & V \\
\hline 23 & Supandi, 2017 & $\nabla$ & V & $\sqrt{v}$ & 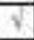 & & & & $\sqrt{ }$ & & & & 1 & & & & & & $\sqrt{1}$ & 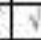 & T & $\checkmark$ & & $\checkmark$ & $\sqrt{1}$ & 8 & $\sqrt{2}$ & & $\sqrt{1}$ & $\sqrt{ }$ & $\sqrt{ }$ & & & & 7 & V \\
\hline 24 & $\begin{array}{l}\text { Edwarsyah, } \\
2017\end{array}$ & & & & & 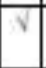 & $\sqrt{ }$ & $\sqrt{ }$ & 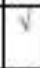 & & & & $\sqrt{1}$ & & & & & & & & & & & $\sqrt{1}$ & $\sqrt{\gamma}$ & $\sqrt{ }$ & $\sqrt{ }$ & & $\mathrm{v}$ & & & & & $\checkmark$ & $\sqrt{3}$ & $\sqrt{ }$ \\
\hline 25 & \begin{tabular}{|l} 
Ervianto, \\
2018 \\
\end{tabular} & $\sqrt{ }$ & $\sqrt{1}$ & & & & & & & & & $\sqrt{1}$ & $v^{2}$ & $\sqrt{1}$ & & 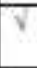 & 8 & $\sqrt{1}$ & & & & V & & & & & & & & & $\nabla$ & $\sqrt{ }$ & & $\checkmark$ & $\pi$ & $\mathrm{V}$ \\
\hline 26 & $\begin{array}{l}\text { Marusabessy, } \\
\text { 2018 }\end{array}$ & & 1 & & & \begin{tabular}{|l|}
+1 \\
\end{tabular} & $\nabla$ & $\nabla$ & $\sqrt{2}$ & +1 & & 7 & $x$ & $\nabla$ & & & & $\sqrt{1}$ & & & & & & $\nabla$ & $\sqrt{ }$ & $\sqrt{7}$ & $\sqrt{2}$ & & $\sqrt{2}$ & & $\nabla$ & & & $\nabla$ & $\sqrt{13}$ & $\bar{v}$ \\
\hline 27 & $\begin{array}{l}\text { Handadari, } \\
2018\end{array}$ & $\sqrt{ }$ & $\sqrt{7}$ & & & $\sqrt{\mathrm{V}}$ & & $\sqrt{ }$ & $\sqrt{ }$ & $\nabla$ & & $\sqrt{1}$ & $\sqrt{1}$ & $\sqrt{1}$ & & & & $\sqrt{ }$ & & & & $\bar{v}$ & $\sqrt{1}$ & $\sqrt{ }$ & $\sqrt{7}$ & $\sqrt{ }$ & 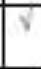 & $\sqrt{ }$ & $\sqrt{ }$ & & $\nabla$ & & & & 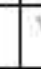 & $\sqrt{7}$ \\
\hline
\end{tabular}

Source: from various journal references and proceedings.

\section{The Concept of Sustainable Small Island Development:}

Basically the concept of small island development refers to the concept of development of coastal areas even though the ecosystems that exist in small islands may be more diverse than in the mainland coastal areas or large islands. In addition, considering that the small island is separated from the mainland (mainland), the accessibility factor can be a significant development constraint in the previous section which has been touched on one of the boundaries of the 
small island. Other restrictions given by several other experts are as follows. A small island is an island with an area of less than 1,000 km2 and / or a population of less than 100,000 people (Brookfield, 1990). Similar definitions are also used in Japan (Nakajima and Machida, 1990).

Reid (1995) in Kay and Alder (1999) suggested that the concept of sustainable development has 4 main influences in the management of coastal areas, namely:

1. Integrated concept of "equity", environment and economy in the paradigm of decision making;

2. Specially considered economic aspects;

3. Special consideration for environmental aspects;

4. He considered specifically the socio-cultural aspects

Next he stated the requirements for sustainable development to be realized, namely:

1. Integration between conservation and development;

2. Satisfaction with basic human needs;

3. Opportunities to meet human needs that are "non material";

4. Developing towards social justice and welfare;

5. Respect and support cultural diversity;

6. Providing opportunities for social self-determination and fostering self-dependence; and

7. Maintain ecological integrity

Cicin-science and Knecht (1998) suggested that sustainable development includes 3 emphases, namely:

Economic development to improve the quality of human life;

Development in accordance with the environment;

Development in accordance with welfare justice, i.e. justice in distributing benefits from development which includes:

1. "Intersocietal equity" for example between groups in the community respects the special rights of local communities and others;

2. "Intergenerational equity" that is not to limit opportunities or choices for future generations;

3. "International equity" is fulfilling obligations (bonds) to other nations and the international community given the reality of global interdependence.

The dependence of economic development on effective management of natural resources and on maintaining sustainable results from ecosystems on the concept of sustainable development, gave rise to the concept of ecologically sustainable development (OECD, 1993). In principle, the meaning of the concept of sustainable development with the concept of ecologically sustainable development is the same, only emphasis is placed on the importance of guaranteeing and passing on to future generations a quantity of natural capital that can provide an economically sustainable outcome and environmental services including natural beauty (amenities).

Insular small islands do have many constraints in development, especially from an economic aspect, the small size is not really a weakness if producers and consumers are local (Brookfield, 1990). However, there are rarely such conditions in this era of globalization so that the small size of the island often becomes an obstacle to economic development (Hess, 1990). Small islands usually have to bear the burden of greater contributions to build infrastructure, education, research, marketing, etc. so that trading activities run smoothly (Hein, 1990). If this cannot be done then economic development on the small island will be slow. This also means that the small island is very dependent on aid and outside the island (Hein, 1990).

Ecologically, insularity also has the consequence of having to make an evaluation of endemic species and decrease the resilience of flora, fauna, and humans, from outsiders (Hein, 1990). Besides the existence of ecological vulnerability, the small island environment also contains many advantages (Hein, 1990b). Despite many obstacles, there are a number of small islands that have succeeded in building into developed islands (Webster, 1990).

\section{Conclusions And Upcoming Research:-}

From various previous studies, it can be concluded that the variables chosen for determining the sustainability of small island development can be categorized in the socio-cultural, economic and ecological aspects. This variable 
will be arranged indicators or factors found in previous studies. The indicators compiled by researchers are 48 indicators that can be seen in the table below.

Table 2:- Variables and indicators of the sustainability of small island development.

\begin{tabular}{|c|c|c|}
\hline \multirow{2}{*}{$\begin{array}{l}\text { Variable } \\
\text { Socio-cultural }\end{array}$} & \multicolumn{2}{|c|}{ Indicator } \\
\hline & 1 & Human Development Index (HDI) \\
\hline & 2 & Population growth \\
\hline & 3 & Population density \\
\hline & 4 & Nutritional status of the community \\
\hline & 5 & Life expectancy \\
\hline & 6 & Infant, mother and child mortality rates \\
\hline & 7 & Number of Diseases \\
\hline & 8 & Number of Health Workers \\
\hline & 9 & Level of education \\
\hline & 10 & Local Cultural Values \\
\hline & 11 & Society participation \\
\hline & 12 & Community Perception \\
\hline & 13 & Community Behavior \\
\hline & 14 & Number of poor people \\
\hline & 15 & Community Institution \\
\hline & 16 & Criminality \\
\hline \multirow{16}{*}{ The economy } & 1 & Income \\
\hline & 2 & Business / Work Opportunities \\
\hline & 3 & Street \\
\hline & 4 & Port / dock \\
\hline & 5 & Sea Transportation \\
\hline & 6 & Electric Energy Sources \\
\hline & 7 & Waste management \\
\hline & 8 & Drinking / Clean Water Services \\
\hline & 9 & Drinking / Clean Water Quality \\
\hline & 10 & Means of trade \\
\hline & 11 & House condition \\
\hline & 12 & Catch of the sea \\
\hline & 13 & Labor \\
\hline & 14 & Unemployment number \\
\hline & 15 & Local Own Revenue (PAD) \\
\hline & 16 & Telecommunication \\
\hline \multirow[t]{16}{*}{ Ecology } & 1 & Mangrove Ecosystem \\
\hline & 2 & Coral Reef Ecosystem \\
\hline & 3 & Seagrass Ecosystem \\
\hline & 4 & Fisheries Resources \\
\hline & 5 & Coastal Abrasion Disaster \\
\hline & 6 & Extreme Waves Disasters \\
\hline & 7 & Earthquake Disasters \\
\hline & 8 & Rob Flood Disaster \\
\hline & 9 & Marine biodiversity \\
\hline & 10 & Green open space \\
\hline & 11 & Sea Water Quality \\
\hline & 12 & Waste Management \\
\hline & 13 & Drainage Network \\
\hline & 14 & Sea level rise \\
\hline & 15 & Air quality \\
\hline & 16 & Land Use \\
\hline
\end{tabular}

Source: Journal review results. 


\section{Future Research:}

Future research is expected to be able formulate a new index based on variables and indicators that have been prepared so that it can be used to measure the sustainability of small island development and can make an appropriate model based on the sustainability index of small island development.

\section{Acknowledgement:-}

A big thank you to the Bosowa University graduate program, especially in the doctoral study program in regional and city planning which has provided a very comfortable research room so that this writing can run smoothly, and we thank the supervisor team who provided advice and input on writing this will enrich the reference of doctoral research that we will do.

\section{References:-}

1. Andi, Y., et al. (2017). "Sustainable Coastal Reclamation Model Case: Makassar City Beach." TATALOKA 19 (4): 339-354.

2. Azwar, SA, et al. (2013). "Model of sustainable urban infrastructure at the coastal reclamation of North Jakarta." Procedia Environmental Sciences 17: 452-461.

3. Baldemir, E., et al. (2013). "A management strategy within a sustainable city context: Cittaslow." ProcediaSocial and Behavioral Sciences 99: 75-84.

4. Brookfield, HC (1990). An approach to the island, In Beller, W, W, P. d'Ayala, management of small island. Man and the Biosphere Series, Vol. 5 UNESCO and the Parthenon Publishing Group, Paris. Page: 23-33.

5. Budiharjo, Eko and Sujarto, Djoko. (1999). Sustainable Cities, Alumni Publisher. Bandung

6. Burhanuddin, Selintung, Wikantari. (2012). Priority for Sustainable Infrastructure Development on Barrang Lompo Island by using the AHP (Analytical Hierarchy Process) Analysis Method. UNHAS Postgraduate Program E-Journal.

7. Cicin-science, B. and RW Knecht. (1998). Integrated coastal and ocean management. Island Press. Washington DC

8. Edwarsyah, E. and R. Safrina (2017). "Index and Sustainability Status of Outermost Small Island: Case Study of the Pulo Raya Aceh Jaya Coast." Tropical Fisheries Management Journal 1 (1): 51-58.

9. Ervianto, WI (2018). "Study of Sustainable Cities in Indonesia (Case Study of Yogyakarta City)." Civil Engineering Media 16 (1): 60-65.

10. Farhan, A. and S. Lim (2012). "Vulnerability assessment of ecological conditions in Seribu Islands, Indonesia." Ocean \& Coastal Management 65: 1-14.

11. Feng, L., et al. (2014). "Assessing coastal reclamation suitability based on a fuzzy-AHP comprehensive evaluation framework: a case study from Lianyungang, China." Marine pollution bulletin 89 (1-2): 102-111

12. Fernandes, JP, et al. (2017). "Using modeling tools for implementing feasible land use and nature conservation governance systems in small islands - The Pico Island (Azores) case study." Journal of environmental management 189: 1-13.

13. Handadari, ASK, et al. (2018). "Index of Marine and Coastal Sustainability in Bali's Benoa Bay Reclamation Location." National Marine Journal 13 (3): 121-136.

14. Hein PL (1990b). Between Aldabra and Nauru, In Beller, W, W, P. d'Ayala and P. Hein (editors), Sustainable development and environmental management of small island. Man and the Biosphere Series, Vol. 5 UNESCO and the Parthenon Publishing Group, Paris. Pages: 57 - 75.

15. Hess, AL (1990). Overview of sustainable development and environmental management of small islands, In Beller, W, W, P. d'Ayala and P. Hein (editors), Sustainable development and environmental management of small islands. Man and the Biosphere Series, Vol. 5 UNESCO and the Parthenon Publishing Group, Paris. Hal: 3-14.

16. Karlina, I. (2015). "Evaluation of the sustainability of the management of the Regional Water Conservation Area (KKPD) Region I, Region II and Region III Natuna Regency." Maritime Dynamics V (2): 8.

17. Mandala, WF (2016). "Constraints and Strategies for Waste Management in Barrang Lompo Island." The Journal of Fisheries Development 2 (2): 61-68.

18. Marasabessy, I., et al. (2018). "The Coastal and Sea Sustainable Management Strategy of Nusa Manu Island and Nusa Leun Island in Central Maluku Regency." Journal of Regional and Rural Development Planning 2 (1): 1122.

19. OECD (1993). Coastal zone management: integrated policies. Organization for Economic Co-operation and Development, Paris. 
20. Pakzad, P., et al. (2017). "Developing key sustainability indicators for assessing green infrastructure performance." Procedia engineering 180: 146-156.

21. Persada, C., et al. (2014). "Determination of the status of urban infrastructure sustainability (case study: Bandarlampung city)." Journal of Social Economics Public Works 6 (1).

22. Pourebrahim, S., et al. (2010). "Analytic network process for selection criteria in sustainable coastal land use planning." Ocean \& Coastal Management 53 (9): 544-551.

23. Qin, X., et al. (2015). "Quantitative models for assessing the human-ocean system's sustainable development in coastal cities: The perspective of metabolic-recycling in the Bohai Sea Ring Area, China." Ocean \& Coastal Management 107: 46-58.

24. Rosales, N. (2011). "Towards the modeling of sustainability into urban planning: using indicators to build sustainable cities." Procedia engineering 21: 641-647.

25. Sarte, S.Bry. (2010). Sustainable Infrastructure, The Guide to Green Engineering and Design. Jhon Wiley and Son Inc. New Jersey.

26. Selintung, M., et al. (2013). "Study on Clean Water Supply Systems in Barrang Lompo Island, Ujung Tanah District, Makassar City."

27. Setiawan, B. "Indicators of Sustainability of Cities in Indonesia: a Comparative Study of Four Cities in Java (Sustainability Indicators of Indonesian Cities: Comparative Studies of Four Cities in Java)." Journal of Humans and the Environment 14 (1): 1-14.

28. Supardi, S., et al. (2017). "Analysis of Sustainable Development of Coastal Cities (Case Study: Baubau City, Southeast Sulawesi Province)." Regional and Environmental Journal 5 (3): 188-204.

29. Sugandhy, A. (1998). Environmental Management of small islands. Proceedings of the seminar and Workshop on Small Island management in Indonesia, Jakarta, 7-10 December 1998. MoFor-BPPT-CRMP (USAID) Cooperation, Jakarta. Page: H1-H4.

30. Supriatna, Heru. (2007). Strategy for Water Resources Infrastructure Development Through the Integrated Coastal Management Approach in the Port Ratu Bay Coastal Area. Digital Library of the ITpil and Environmental Engineering faculty of ITB.

31. Susilo, SB (2007). "Analysis of the sustainability of small islands development: an ecological-economic model approach." Indonesian Journal of Aquatic Sciences and Fisheries 14 (1): 29-35.

32. Tahir, A., et al. (2012). "Small Island Vulnerability Index: The Case of Barrang Lompo-Makassar Island." Marine Sciences: Indonesian Journal of Marine Sciences 14 (4): 183-188.

33. Wang, C., et al. (2016). "Measuring regional sustainability with an integrated social-economic-natural approach: a case study of the Yellow River Delta region of China." Journal of Cleaner Production 114: 189-198.

34. Wardhani, MK and A. Farid (2017). "Dynamic Model of Vulnerability in Poteran Island and Gili Lawak Beach, Sumenep Madura Regency." Marine Journal: Indonesian Journal of Marine Science and Technology 10 (1): 78 86.

35. Webster, J. (1990). The ecological sustainability of economic growth in the isle of man, In Beller, W, W, P. d'Ayala and P. Hein (editors): Sustainable development and environmental management of small islands. Man and the Biosphere Series, Vol. 5 UNESCO and the Parthenon Publishing Group, Paris. Page: 183 - 196.

36. Widodo, PW, et al. (2015). "Evaluation of Small Island as a Basis for Ecotourism Investment Development (Case Study of Tidung Kecil Island, Kepulauan Seribu Regency, Dki)." Journal of Marine Economic and Fisheries 10 (1): 77-90.

37. Yu, L., et al. (2010). "Assessment of coastal zone sustainable development: A case study of Yantai, China." Ecological Indicators 10 (6): 1218-1225.

38. Yurnita, A., et al. (2018). "Assessment of the Sustainability of the Jakarta Beach Reclamation Using a Geographic Information System Approach" Plano Madani: Journal of Regional and City Planning 6 (2): 185194.

39. Zhou, J., et al. (2007). "Assessment of sustainable development systems in Suihua City, China." Chinese Geographical Science 17 (4): 304-310. 